\title{
Feeding Intolerance
}

National Cancer Institute

\section{Source}

National Cancer Institute. Feeding Intolerance. NCI Thesaurus. Code C113395.

Inability to achieve a full feeding volume. 